\title{
Adoption of ICTs in Agri-Food Logistics: Potential and Limitations for Supply Chain Sustainability
}

\author{
Cédric Vernier ${ }^{1}$, Denis Loeillet ${ }^{2}$, Rallou Thomopoulos ${ }^{3, *} *$ and Catherine Macombe ${ }^{1}$ \\ 1 ITAP, INRAE, Institut Agro, 34060 Montpellier, France; cedric.vernier@outlook.fr (C.V.); \\ catherine.macombe@inrae.fr (C.M.) \\ 2 GECO, CIRAD, 34398 Montpellier, France; denis.loeillet@cirad.fr \\ 3 IATE, University of Montpellier, INRAE, Institut Agro, 34060 Montpellier, France \\ * Correspondence: rallou.thomopoulos@inrae.fr
}

Citation: Vernier, C.; Loeillet, D.;

Thomopoulos, R.; Macombe, C.

Adoption of ICTs in Agri-Food

Logistics: Potential and Limitations for Supply Chain Sustainability.

Sustainability 2021, 13, 6702

https://doi.org/10.3390/su13126702

Academic Editors: Anet

Režek Jambrak and Ilija Djekic

Received: 12 May 2021

Accepted: 6 June 2021

Published: 12 June 2021

Publisher's Note: MDPI stays neutral with regard to jurisdictional claims in published maps and institutional affiliations.

Copyright: (c) 2021 by the authors. Licensee MDPI, Basel, Switzerland. This article is an open access article distributed under the terms and conditions of the Creative Commons Attribution (CC BY) license (https:/ / creativecommons.org/licenses/by/ $4.0 /)$.

\begin{abstract}
A major challenge of Sustainable Development Goal 12 "Responsible Consumption and Production" is to reduce food losses along production and supply chains. This is particularly critical for fresh food products, due to their perishable and fragile nature, which makes the coordination of the actors all the more crucial to avoid wastes and losses. The rise of new technologies, referred to as "Industry 4.0 " powered by the internet of things, big data analytics and artificial intelligence, could bring new solutions to meet these needs. Information and communication technologies (ICTs) allow for frequent exchanges of huge amounts of information between actors in the agrofood chains to coordinate their activities. The aim of the chapter is to provide a state-of-the-art analysis on ICTs used in agrofood supply chains, with a special focus on the case of fresh fruits and vegetables, to analyze the potential and weaknesses which exist in different forms of supply chains for ICTs becoming a "resource" (precious, rare, non-imitable, and nonsubstitutable) prospect and to suggest promising ICTs in this context.
\end{abstract}

Keywords: food sustainability; food supply chain; innovation in food; food waste and SDGs; ICTs

\section{Introduction}

Driven by the evolution of consumer demand towards increased sustainability and the desire to improve efficiency, agrofood supply chains are following a trend of redesigning their logistics [1]. Citing Target 12.3 of Sustainable Development Goals [2], ensuring sustainable consumption and production patterns means to "reduce food losses along production and supply chains, including post-harvest losses". For instance, between $25 \%$ and $30 \%$ of the fruit and vegetables produced in India are lost due to insufficient transportation and distribution facilities [3]. Logistics management is acknowledged as one of the essential processes to reduce food waste within supply chain management [4].

Concomitantly, the rise of new technologies could bring new solutions to meet these needs [5]. Among them, information and communication technologies (ICTs) promote frequent exchanges of huge amounts of information between actors in the agrofood chains to coordinate their activities [6]. Organizations are using digital technologies to change the value-creation paths they previously relied on to remain competitive [7].

A special focus concerns the case of fresh fruits and vegetables [8], due to the perishable and fragile nature of these products. Indeed, it makes the coordination of the actors all the more crucial to avoid waste and damage during the order [9]. As distribution channels increasingly make use of ICTs [10], and as the tools and practices are not evenly shared, there is a need to improve knowledge on how they relate to digital resources. ICT tools used in the fresh fruits and vegetables sector are the same as for other goods. However, supply chains experience short lifetimes and fragility of commodities. Inventory turnarounds are faster, under cold chain conditions, and handling operations are more delicate to avoid damage. Moreover, the margins obtained from these value-chains are tiny, so one can 
expect that any new tool (like ICTs) will not be adopted in the long run unless it provides a clear advantage.

By ICTs, the paper refers to all telecommunication, information, internet, multimedia and audiovisual technologies [11] that make it possible to process, modify and exchange information, and more specifically digitized data. Those allowing exchanges between actors in agrofood supply chains including consumers [12] are highlighted in this paper, focusing on ICTs used in the logistics activity in B-to-B (business to business). For food products, logistics is the series of operations from the purchase of raw materials to the distribution of the final product. It aims to provide the consumer with the desired product in the right quantity, at the right place, at the right time and at an acceptable cost [13].

The paper will examine the diversity of ICTs in different agrofood supply chain contexts, and their different functionalities. Moreover, it is an exploratory research work, relating to ICTs seen as "resources" [14]. From [14], a resource is "all the assets, capacities, organizational process, attributes of the enterprise, information, knowledge, etc., controlled by the enterprise allowing for conceiving and implementing strategies to improve effectiveness and efficiency" [15]. The authors will examine the conditions that mean ICTs are becoming a strategic resource, through the presented examples. In the theory of management known as the "resource-based view" (RBV), the strategic resources are the ones that confer "core competencies" [16] to the firm, or to the value-chain. The building and conservation of the core competencies are necessary conditions for the long term of the company/value-chain. The research question is therefore, "what are the conditions for ICTs used in the agrofood supply chain to be a strategic 'resource' for the agrofood supply chain?"

The research questions addressed are therefore two-fold: What is the adoption, difficulties and future of ICTs in the fresh fruit and vegetable supply chain in France, from the representation of the supply chain's actors? What are the conditions for ICTs used in the fresh fruit and vegetable supply chain to generate knowledge which would be a strategic 'resource' for the company or the supply chain?

The aim of the paper is to obtain knowledge about adoption of ICTs in the fresh fruit and vegetable supply chain in France, with four objectives:

- Provide a state-of-the-art analysis on ICTs used in fresh fruit and vegetable supply chains.

- $\quad$ Discuss the difficulties to implement ICTs in this sector.

- Qualitatively analyze the potential in certain ICTs leading to building of strategic "resources".

- Deliver an outlook and suggestions for promising information systems in the fruit and vegetable sector.

The rest of the paper is organized as follows. Section 2 details the materials and methods of the review. Section 3 suggests a classification of ICTs according to their functionalities. This section addresses multitasking tools common in all contexts; generalist ICT tools to formalize interactions between actors in the agrofood supply chain; specific software to optimize the internal organization of societies; ICTs to manage conflicts; collaborative ICTs (in long chains, in short chains and in Traditional Retail Markets). Section 4 identifies and discusses several difficulties to adopt new ICTs in the logistics of fresh fruit and vegetables. Section 5 deals with the analysis of ITCs regarding their potential as generating strategic "resources" through three topics: ICTs control; club effect; secrecy of collaboration. Finally, a vision of the future of information systems in the logistics of agrofood supply chains is outlined in Section 6, before the conclusive Section 7.

\section{Materials and Methods}

The first paragraph (Section 2.1) depicts the kind of materials gathered for this research and the collection operations. How the ICTs tools in use have been classified is the object of the second paragraph (Section 2.2) while the third (Section 2.3) explains the method mobilized to examine the role of ICTs in building potential strategic resources. 


\subsection{Materials \& Data Collection}

To perform the research in the fruit and vegetable sector, the authors of the paper used three channels of information: scientific literature, grey literature and exchanges with professionals from different fields (actors from the food network, including two experts from Cirad). Although several modeling approaches have been proposed to solve cold-chain management issues in the fruit and vegetable sector $[3,17]$, the published scientific papers about the actual implementation of ICTs in the fruit and vegetable sector are scarce [18,19]. Citing the recent study by [20] (p. 112) on Industry 4.0 (I4.0) across all sectors, "Despite the amount of attention that I4.0 has received in the media and in the policy debate, little robust evidence is available on the diffusion of such technologies". Consequently, the main source of information on actual practices is grey literature (from professional bodies, social media and conferences) and interviews. The methods in use are qualitative [21] because the purpose of the research is to gather non-numerical data, to understand what kind of phenomena are occurring, how and why. Moreover, all the results are drawn from the representations of the interviewed actors because the authors of the paper did not perform a survey within the facilities of the companies themselves.

Searches were performed via scientific resource databases with contractual access (Web of Science, Scopus, Econlit, Food Science Source, Tair, ... ) or open access (HAL, ORBi, ... ), as well as Google Scholar. The main keywords tried were "logistics", "fruit and vegetable" and "ICT". The searches were complemented by a subscription to RSS feeds on the Fruit Logistica website, as well as monitoring some media (Digital Supply Chains or Logistics Strategies) and professionals on Twitter or LinkedIn, such as Richard Van Hooijdonk, Chris White or Fabien Esnoult. Questions were asked about the publications made on these pages through the comments system (presence of ICTs and their functionalities).

Conferences were followed during two professional congress and exhibition events, namely "Fruit Logistica 2018" in Berlin, and "SITL 2018" (International Logistics Week) in Paris. These events enabled a perception of the diversity of implemented ICTs in the logistics of fresh fruit and vegetable, and interacting with professionals on the present, the difficulties of adoption and the future and sustainability of ICTs in the sector. Nineteen interviews held during the "Berlin Fruit Logistica" were mobilized for this study. The respondents occupied very different positions, from event coordinator to export manager, sales manager and marketing manager. Six different areas of activity were represented in the sample, namely ICT sales, logistic solutions, quality control, certification, port and agricultural product distribution. ICT sales companies accounted for more than half of the sample. The "logistics solution" area referred to companies offering, for example, transportation solutions or advice on logistics tools. The other activities were quality control, certification, one representative of a port and one distributor of agricultural products. The breakdown of the companies according to their field of activity is represented in Figure 1.

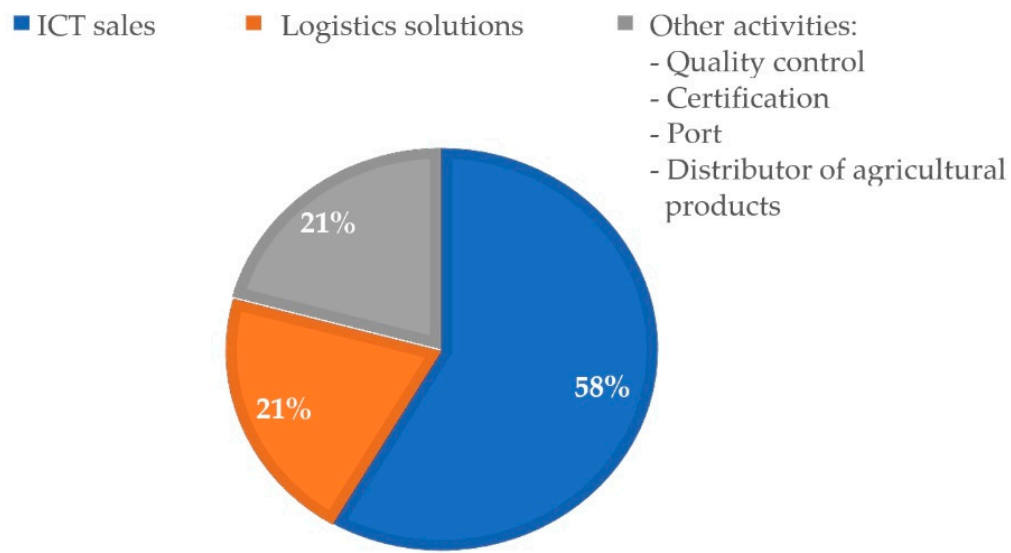

Figure 1. Breakdown of the companies interviewed during the Berlin Fruit Logistica 2018 exhibition event, by their field of activity $(n=19)$. 
Two more interviews with experts of fresh fruit and vegetables from Cirad were also mobilized, especially about the future and sustainability of ICTs in this sector.

During Berlin's event, the authors conducted interviews with the people on the stands, according to the method of semidirective interview by [22]. This method detects the underlying structuring of the prospect's thinking (about the issue under scrutiny), without imposing the structuring pre-defined by the researcher (as would be the case with questionnaires). The first question asked to the prospect is "What are the problems your products face?" for the "ICT sales" area of activity, and "what digital tools does your structure use?" for the others. Then a discussion follows. Other issues are about the future of ICTs in logistics, the problems encountered with ICTs, and their potential support to the sustainable development of the supply chain. A list of questions guiding the interviews is presented in Table 1. The interviews could last between 5 and 15 minutes in English, Spanish or French. On the first day, the representatives of three fruit companies gave interviews. These three companies were delegating their logistics activity to a third company. They were unable to cite ICTs used in the distribution of their products. Thus, no other companies of this field were approached by the investigator. In the following days, companies that produced ICTs were approached. After a dozen interviews, little new information was obtained. The same answers to the same questions were repeated more and more during the three days. This is the sign that the number of interviews reached the so-called level of "saturation" of the sample [23]. This theoretical saturation is obtained when one finds neither supplementary data generating theoretical highlights nor new properties of the main categories [24].

Table 1. Topics guiding the interviews.

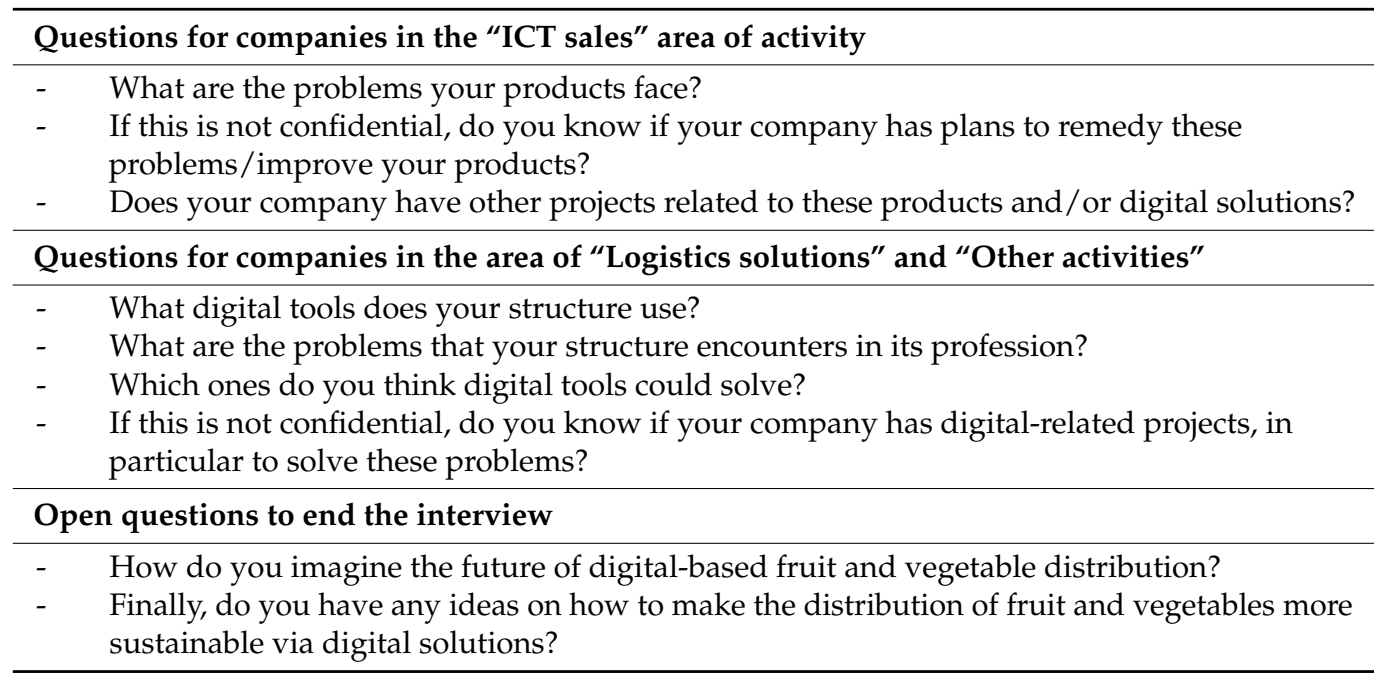

\subsection{Method of Classification for the State-of-the-Art ICTs}

Ref. [25] suggest a classification of ICTs used in logistics of food supply-chain, regarding their main contribution to execution level (for transportation, warehousing ... ), value-adding level (for labeling, packaging ... ) and planning/control level (to react to unexpected events...). In the present paper, the classification is also arranged by functionality, but following the structuring spontaneously elicited from the interviewed actors themselves.

The interviews highlighted that supply chain actors distinguish the ICTs tools according to the following 5 categories: multitasking tools; generalist tools; specific software for logistics; ICTs to manage conflicts; and collaborative ICTs. Thus, the ICT tools are presented according to this typology in Section 3.

The difficulties encountered by respondents to adopt ICTs in their own company, as well as their opinions about future development and issues of sustainability of ICTs, are 
simply reported. It is the same for the opinions of the Cirad experts as well, about future and sustainability of the sector and associated ICTs.

\subsection{Method for Analyzing ICTs as Generating Strategic Resources}

To feed the second research question ("what are the conditions for ICTs used in the fresh fruit and vegetable supply chain to generate knowledge which would be a strategic 'resource' for the company or the supply chain?"), an analysis was conducted to match the properties of the knowledge drawn thanks to certain ICTs in use and the features of a strategic "resource" (Section 5). As already highlighted above, for the resource-based view (RBV), not all resources are of equal importance. The strategic resources are the ones that confer "core competencies" [16] to the firm, or to the supply chain.

The authors used the grid developed by [14] presenting strategic "resources" as precious, rare, difficult to imitate and to substitute, through three topics. The first one is about the actor/s controlling the ICTs: is it a regular player within the company/supply chain, or is it an external one? The answer gives a clue of the importance given to the ICT by the traditional actors (the ICT is deemed to be rare and precious, if an internal actor of the supply chain owns and controls it). The second issue is about the creation of a "club effect", i.e., whether the ICTs provide the company or supply chain with services that are exclusively devoted to their own and never offered to newcomers without the agreement of the original users? Finally, the third topic revolves around the ICTs allowing collaboration between different actors of the supply chain, and the features of the advantages provided by certain forms of collaboration. In case of collaboration, the competencies stemming from ICTs are deemed rare and precious because they are based upon a great deal of specific links between the collaborating actors.

\section{A Classification of ICTs According to Their Functionalities}

The complexity of different ICTs governs their use. Those requiring longer learning will be considered sophisticated, and they will tend to be more expensive. They will preferentially be found in developed countries. In general, the more sophisticated the ICTs, the more specific they will be to Western distribution channels. Whatever the tool, their common purpose is to improve coordination of actors. Indeed, it is vital for the food network "to work as a single entity to plan and control the logistics of food products in a more effective and efficient way and supply consumers with high quality and secure food." [25] (p. 138). As [26] highlighted it for IBM workers, ICTs allow connected actors to effectively coordinate their activities when they are in the same place, but also when they are distributed in different locations, which is common in globalized food chains.

\subsection{Multitasking Tools Common in All Contexts Such as the Mobile Phone}

Mobile phones have the advantage of allowing live conversations with a spatially remote partner. They are in common use whatever the socioeconomic context, i.e., even when other more sophisticated tools are available [27]. They provide several functions [28]. The first is the provision of information. The actors are able to know the quantities, the quality and the prices of the goods handled by the upstream actors [27,29]. Negotiations can begin during the call [27], followed by the order placement and organization of the transport [29]. Wholesalers also use their phones to sell perishable goods as quickly as possible [27]. Unless SMS or voicemail are used, there is no physical trace of the exchanges. Mobile phones are usable by illiterate people [30]. In the event of a dispute, telephone exchanges cannot be considered authentic.

In case of Collective Sale Point (e.g., "Coopérative Couleurs Paysannes”, France, Alpes de Haute-Provence), the mobile phone provides information about the state of stocks in the shop. The requests for information stem from the manager towards the producers, or the other way round. In the longer term, this cooperative plans to set up a tool to obtain this information online. Otherwise, the low predictability of sales makes transportation and production difficult to plan. 
Mobile phones are usable by illiterate people [30]. In the traditional retail markets of developing countries, with a relatively high rate of illiteracy, the other "multitasking tools" are landline phones, and courier and messengers carrying a verbal message. However, the mobile phone is the most common one. A total of $80 \%$ of households are equipped with smartphones, although most of them have no web access, as the infrastructures are not connected. According to [31], 60\% of the world's population has no web access.

\subsection{Generalist ICT Tools to Formalize Interactions between Actors in the Agrofood Supply Chain}

The generalist tools require internet access and deliver three functions. First, as for mobile phones, they support exchanges in B-to-B or with customers. Second, unlike mobile phones, e-mail or EDI (Electronic Data Interchange) systems keep a written record of the interaction. EDI is a standardized system for the exchange of physical documents (orders, invoices, delivery notes, etc.) thanks to computers connected by specialized links such as extranets [12,32]. Farmers also use websites [33]. They present on-line the products they offer to customers, and some websites even allow online ordering and payments [34]. Third, the internet also makes it possible to search for more general information. For example, it can be useful to search for business partners via directories of professionals. Various types of information are posted on product information platforms. The Fructidor site for instance, mainly contains information on market trends. Nevertheless, articles on technological innovations or upcoming professional events are also present. The site offers the possibility to subscribe to newsletters. The company Huercasa plans to set up a platform gathering technical information on their products (origin, applied phytosanitary treatment, quality control checks, etc.).

Unlike the mobile phone, the use of these generalist tools requires one to be literate and have some know-how about the basic functions of a computer. These ICTs are particularly usual for short circuits in advanced socioeconomic contexts. Long circuits also use them, whereas their presence is much rarer for traditional retail markets [29].

\subsection{Specific Software to Optimize the Internal Logistic of Companies}

Degrees of complexity differ one from the other in this category. For short circuits in advanced contexts, inventory management and order preparation can be done using spreadsheets. The most advanced short circuits are able to use specific software for the inventory and order preparation functions, or to borrow the Transport Management System (TMS) from their Agricultural Equipment Utilization Cooperative (CUMA) according to [34]. For circuits where the flow of merchandise is larger, a hub or long circuit, the use of software such as ERP (Enterprise Resource Planning) or WMS (Warehouse Management System) is usual.

ERP mainly supports companies in tracking orders. It collects all the data relating to a commodity from entry to exit. It is used to trace the products and to list the different transactions for each customer. Thanks to the data collected via ERP, some platforms enable companies to compare themselves with others. The digital pallets management system PAKI is a simpler tool. For each transaction, the parties indicate on their online account the variation of their pallet stock. The operations described by e-vouchers indicate a credit or a flow of pallets. The company picks surplus pallets up from customers for redistribution and offers the replacement of damaged pallets.

Warehouse management system (WMS) software is designed to optimize pallet storage in a warehouse. It also states which pallets are to be removed first, on a "First In-First Out" basis, for example. Today, with the replacement of humans by mechanization, WCS (warehouse control system) software is developing. It directs the activity in real time within the warehouses (Source: KLS Group).

New tools to optimize internal organization are continuing to emerge. The "Easy Check In" smart terminal smooths and optimizes delivery truck traffic in warehouses [35]. The reception desk at the entrance of the warehouses is comparable to the warehouse's secretary. It identifies incoming trucks by scanning their license plates and tells them where 
to stand on the dock while waiting for their turn to load or unload the goods. Before the truck leaves, it directly prints the administrative documents that the drivers must sign after their operations. The "ZetesOlympus" platform provides a real-time panorama visibility to the distributor throughout its supply chain $[35,36]$. Alerts are given to anticipate any disruption to product availability. This platform is particularly relevant for entities with many partners. The Marks \& Spencer group, which has numerous suppliers and logistic partners, employs this platform to monitor the supply chain of its fresh products [36].

The abovementioned software programs are helping companies optimize their logistics activity. Because of their high price, small and medium enterprises employ basic, cheaper software (such as office suite tools) instead. As expected, the larger the agrofood companies, the greater the use of ICTs [37].

\subsection{ICTs to Manage Conflicts}

The technologies presented in this section help long-chain companies in functions facilitating and accompanying transport. This is called "litigation management", or proceedings for insurance covering goods, such as claim declarations or following up a refund. In this sector, the most frequently encountered disputes concern sales and transport. These specific ICTs are present in long circuits of advanced socioeconomic contexts.

Some platforms allow actors to choose partners on an informed basis. For example, "Blue Book Services" is a directory of professionals that indicates whether the listed members have ever been involved in commercial litigation. The Blue Book Services structure and Fruit Insurances Services also offer legal support to their clients. They guide applicant clients to lawyers specializing in transport law, or with knowledge of the fruit and vegetable sector.

Other instruments are used to track the course of products along the chain, and then enable more effective management of conflicts. "BlockChain" emerged for this purpose, as a collaborative process [38] that stores information across the entire supply chain. It tracks the commodities via a variety of information, such as the origin of the products and the operations carried out by the different actors. Conversely, today the majority of information is still circulating in paper format. The search is therefore long and the information provided is not uniform between the actors. Blockchain is also allowing the fresh fruit and vegetable sectors to act faster in the event of an incident, by facilitating access to information [38]. Due to the multiplicity of servers involved, it is almost impossible to erase or falsify information. This would require changing the data on each server in the chain. The information flows through the QR and RFID codes that follow the products. At each step, the actors report their operations via this code [39]. Scanning the code with a smartphone allows anyone to access data. A variety of information is provided in the case of fresh fruit and vegetables. First, there is technical information on agricultural products. Blockchain, developed by IBM and Walmart on tomatoes, records the maturity of food products, their color and their sugar and salt levels. Agricultural sensors on the plots help collect this information as early as the production stage [40]. The same tool can also quickly authenticate labeled foods. It certifies that the product is compliant with the specifications-for instance, certifying that a grape belongs to a particular region ("terroir"), guaranteeing the authenticity of a wine or champagne [40]. Finally, the Blockchain can record economic transactions between actors. It is easier to bring in new information (such as a new supplier or new contractual arrangements). The data are often coupled with an ERP [41].

Managing conflicts is also the main purpose of positioning sensors in containers (with a USB port that can be stuck in the container or hold of an aircraft). By recording at regular intervals the temperature, the ethylene concentration or the hygrometry, it is possible to detect at what moment of the journey the problem occurred. Several product lines exist. The most successful models also record photometry, geolocation or shocks suffered. A peak of light intensity corresponds to the opening of the container during the trip. This event can potentially alter the storage conditions during transport. However, the place of the sensor 
in the container can influence the results. Pelletier noted temperature differences of up to $5{ }^{\circ} \mathrm{C}$ in the same container [42]. At the end of the trip, the data is read by connecting the sensor to the USB port of a computer (live tracking of the claims is possible from computer, tablet or smartphone). The results appear in PDF format, which makes it impossible to falsify the data. An alert message reaches the partner when the file is opened. The system forwards a link to the partner so that they too can access the data. In some countries, lack of GSM or 4G networks makes the use of land tracking in real time impossible [43]. Other companies offer simpler sensors that change color when the temperature is out of compliance. They can also give an idea of the duration of temperature noncompliance. This is especially valuable in large developing countries (like India) where the cold chain is under construction [3].

Finally, some short circuits also use sensors to ensure compliance with the cold chain. The platform "Péligourmet", which facilitates the delivery of goods from short circuits between individuals, uses "cool chips". Stuck on the products, they turn red if the product has spent more than a minute outside the cooler [44].

\subsection{Collaborative ICTs}

Innovations based on collaboration have emerged in recent years, and some are supported by ICTs. Collaboration is defined as "when two or more companies share responsibility for pooling their planning, information on their performance indicators, managing and building their supply chain" [45]. Certain ICTs facilitate use of collaborative devices [9].

\subsubsection{In Long Chains}

With a view to collaborative work, CAD (computer-aided design) type software has emerged. These computer-aided design techniques enable joint design of digital product models [37]. Based on the complementarity of the needs of different actors, they provide the supplier and the recipient with storage space in warehouses and cold rooms [46]. In addition, recent months have seen the emergence of numerous partnerships between retail and logistics companies. For example, Walmart and JD, a retailer and an e-merchant, have put together a common inventory system. When an order is placed, the nearest warehouse containing the commodity is located. It may be a Walmart or a JD warehouse [47]. Other alliances have also emerged with actors specializing in urban logistics. "Carrefour" launched a partnership with "Stuart", while "Intermarché" has opted to use "Shopopop". In the former case, individuals make the delivery by bike. This is the same operation as for takeaway delivery [48]. Conversely, Shopopop offers delivery between neighbors. A customer shopping in-store could deliver, on their way home, another individual's order [49].

\subsubsection{In Short Chains}

On the same principle as the CAD mentioned above, actors share text documents or spreadsheets using collaborative solutions such as Google Drive. In the case of the La Louve grocery store, the tools can also be modified online by several members, and collaborating members use it to jointly place orders with suppliers [33].

Lacombe described in his thesis dissertation the "energy inefficiency" that short circuits in France had to face because of the nonpooling of production factors. Cold rooms and trucks are used individually and often do not reach their maximum capacity [34]. Route optimization of the logistics can improve efficiency up to $90 \%$ as experienced in Sweden [50]. Recent years have seen the emergence of two devices enabled by the ICTs to make up for this deficit. The first is called "Agriflux". It specializes in the management of logistics activities for farmers with short selling circuits to retailers. It has a platform listing the farmers' products. Merchants can select them and place their order via this tool. The company will pick up the goods from the farms. It will store and prepare orders from its logistics platform before delivering them to the retailers. The second, called "La Charrette", 
pools only the transport of commodities. It stems from the same principle as the carpool platform "BlaBlaCar". Users post or search for trips to transport their food [51].

Simpler digital platforms reappear regularly to pool the farmers' production-in most cases the producer group's website. Farmers specify the nature of the products they are selling, the quantities available and the price. They can also provide a description of the commodity. Because the platform includes an online catalog, some websites prompt customers to order directly online [33]. In some cases, customers can also raise their expectations about the contents of the baskets. A third party will then be responsible for reconciling supply and demand for picking the baskets. In the association "La ruche qui dit oui !", this third party is a consumer who plays the role of coordinator. Payments are made on the online platform. As a result, billing and customer tracking activities run through the platform. Once an order is placed via the online platform, the farmer can be notified by e-mail. The association "Eat-Farmer" (France, Haut-Rhin) too has a similar process. An ICT tool synthesizes the orders and facilitates their preparation.

\subsubsection{In Traditional Retail Markets}

The lack of market information likely hinders traditional retail market actors. Data that are lacking include commodity prices demanded by the upstream segment, export prices, volumes supplied, product quality, or transport price [29]. Since 2009, a mobilephone-based platform has been in place in Vietnam. Through an SMS system, the identified actors can enter the selling prices, consult the average price of a commodity, or the prices applied by a given actor.

\section{Difficulties for ICT Adoption}

The literature and respondents agree about the main difficulties to adoption of ICTs, mentioned as misunderstanding of ICTs (Section 4.1), issue of confidence (Section 4.2) and cost (Section 4.3).

\subsection{Misunderstanding of ICTs}

From the literature, the main obstacle to digital technology is misunderstanding of ICTs $[6,43,46]$. Fear of change and misunderstanding a concept can prevent the implementation of an innovation. The lack of understanding of the Blockchain concept thus remains its main drawback [46]. ICTs that are easy to access and use encourage adoption. This is also true for short circuits or traditional retail markets where players may be less comfortable with new technologies [33].

From the interviews, in some developing countries, there are large fresh fruit and vegetable businesses that do not use the internet every day, even if they have access to the web. The respondents think that this hinders the circulation of information between the actors and especially the distribution activity more comprehensively. For ICTs in developing countries, the low literacy rate of the population hampers some usages [30].

\subsection{Confidence and Defiance}

Specific to the logistics sector, the current "paradigm of ownership" hinders the development of collaborative tools [52]. Companies that have made significant investments in their production factors are not keen to share [46]. The Stock-Booking company, which connects warehouse space suppliers and recipients, notes that many members of the sector are reluctant to adopt the concept. In addition to the organizational inconvenience this may cause (too frequent recovery of food products can alter the cold chain, contamination between products, etc.), lending space and indicating the filling percentage of its warehouse still hinders business players. This information may be confidential. The historically rather bad relations between distributors and suppliers also make them reluctant to collaborate [53]. This attitude hinders the entire supply chain. Many companies delivering food, especially in cities, create maps where they list information. They can indicate their locations, their clients' addresses, or other informal information, such as places often avail- 
able for parking. Because of the sensitive information they carry, the cards shared with competitors are highly simplified. A collaborative map, where everyone would indicate information and be able to access data of other users would be of much better quality [43]. Interviews revealed data maintenance problems. The issue most often recorded relates to information storage systems. In general, companies use their own storage systems to manage information [54]. The information tracking the same product is therefore split between the various systems of the different actors. The solution might be to integrate these databases in order to design shared databases. However, changes of tools or operating systems may encounter the problems of confidence mentioned above.

Paradoxically, collaboration is easier to implement horizontally than vertically. The cases of "coopetitions" [55] are numerous and can be found in the various circuits. Longcircuit wholesalers can exchange their goods, and collectors can purchase for their peers [29]. As explained above, vertical collaboration is more difficult because historically the relations are strained. This is mainly due to long and difficult price negotiations [53]. Some large groups use questionable bullying strategies to obtain the lowest prices [56]. It is obvious that one must start by maintaining good relations with partners before thinking about sharing potentially confidential information [57]. Confidence is a key for adopting certain collaborative ICTs, and therefore for building new core competencies supported by ICTs.

\subsection{Cost of Digital Transition}

The fear of change, a brake for human behavior, can also be associated with economic brakes. The adoption of new technologies can be costly [58]. It may be difficult to adopt new tools when one has adopted another technology, which was the technological optimum at a given moment. "Path dependency" generates high transition costs [59]. People in the company (or even in the whole supply chain) have trained to use the past technology, while the facilities and time schedules are adapted to this past technology. As a result, not only potential benefits but also likely important costs are associated with replacing an old tool with a new one. It is the main obstacle to implementation of ICTs identified by [60] in the UK survey of SMEs. The inception of the new tool often entails a period of low activity in the company, to avoid the failures caused by learning new techniques too quickly. However, in the fruit and vegetable sector, business moves at a frenetic tempo, and rarely offers such breaks. Managers have to weigh costs and benefits against adoption of new technology [61]. Moreover, research and innovation are expensive for a company, and firms do not necessarily want to share their results [43]. Sometimes, regulatory issues are triggers for digitalization of companies, but they can also work against it. In some cases, managers choose an innovative system which proves obsolete because of the next regulation, with a huge financial loss for the company.

Accordingly, regarding the less developed countries, the adoption of new digital tools seems easier when starting from a low technological level. For example, South Africa has experienced almost directly $4 \mathrm{G}$ without going through the telephone network. The country has thus directly acquired advanced technologies, and tends to be more inclined to adopt new technologies [62].

From interviews, some places in developing and in developed countries are not equipped for cost reasons. Thus, part of the course occurs in places where there is no $4 \mathrm{G}$, which penalizes the collection of information of trackers in real time.

\section{ICTs Regarding Their Potential as Generating "Strategic Resources"}

Three topics and questions stem from the analysis to know whether the ICT tool under scrutiny confers core competencies, i.e., competencies that are precious, rare, difficult to imitate and to substitute. The first one (Section 5.1) is about the actor/s controlling the ICTs: is it a regular player within the company/supply chain, or is it an external one? The second question (Section 5.2) is whether the use of the ICTs is easy to imitate or substitute. Finally, the third question (Section 5.3) revolves around the ICTs allowing 
collaboration. The Section 5.4 proposes a provisional conclusion about ICTs as generating potential strategic resources.

\subsection{ICT Control: In or Out?}

If the technology is controlled (e.g., implementing the updates) by an external player, it is impossible to consider that it will give birth to strategic resources for the company. This was the case of the three fruit companies interviewed at Fruit Logistica, the first day. The fact that they did not even know which ICTs are in use by their delegate partner for logistics highlights that ICTs do not contribute to the core competence of their supply chain at this point in time-all the same when in the hands of external players who widely spread the technology. This is the case with mobile phones and regular software (e-mail and EDI systems, regular websites, platforms, ERP, WMS) that are controlled by IT and telematics firms. The purpose of the technology firms is to widely disseminate the tools. As a result, usage of these ICTs is very common and similar from one company to another. Nevertheless, it is noticeable that in a context of illiteracy, using EDI can provide a (temporary) strategic advantage, as long as competitors are not able to do the same.

Despite the ICT being controlled by an external player, the service rendered by "La Charrette" tool (and equivalents) allows the farmers (in a short supply chain) to cultivate a core competence of the supply chain (the mutualization of transport). Both facts make this service represent a core competence. First, the activity performs on a limited given territory, such as the group of farmers selling goods through the La Charrette system, and not competing with any other farmers' group doing the same on the same territory. Second, the greater the number of farmers, the more efficient the system. Newcomers find no benefit in creating another "La Charrette" group on the same territory. They prefer to agglomerate into the existing group. Because of this territorial effect, this mutual transport of commodities delivers advantages (effectiveness and efficiency) expected from strategic "resource" in the sense of RBV, without presenting all its features. The service acquired thanks to ICTs is performing (it allows customers to post their queries or bids to transport the food), but the knowledge gained from these ICTs is not rare, and anyone can imitate or substitute them. Nevertheless, when limiting the discussion to a given territory, the first "La Charrette" network experiences the full status of a strategic "resource" because it remains the only one (insofar as it works properly), and no other organization can obtain any advantage from imitating or replacing it-quite the contrary.

\subsection{Club Effect}

When everyone can quickly learn how to handle certain software, it is quite impossible to derive a rare strategic competence from its usage, unless no other company can access this software. In this case, the ICTs concerned become a "club" good (like certain fruit varieties that are exclusively devoted to a specific group of growers). The aim is to make diffusion impossible, and to make imitation and substitution difficult. Some ICTs are more likely to become "club" goods than others, for example, the ICTs designed at the request of the company itself. They might be of the same kind as the "Blue Book Services", if reserved for a specific pool of noncompeting companies. It is also the case of the system of sensors positioned in containers, when its design is so specific that it is non-imitable in practice. The "Blockchain" ICT is demonstrative of the importance of the "club" idea. Many start-ups (newcomers to the agrofood supply chains) are offering a multitude of "Blockchains" (expected to be widely shared), whereas agrofood retailers are seeking to develop their own private Blockchain technology, in an attempt to create a "club" good on their own. This two-pronged race for control of Blockchains demonstrates that the nature alone of the ICTs is not enough for the ICT to become a "club" good; it is the nature of its governance which decides whether it is a club good or not, and so, whether it can contribute to the strategic competencies or not. In the case of sensors and Blockchains systems, a large part of the supply chain (if not all of it) is involved. It is the same for the collaborative ICTs evoked in the next paragraph. 


\subsection{Secrecy of Collaboration}

Some ICTs are specifically devised to support collaboration between several supply chain actors, as can be Blockchain [63]. As described in Section 3.5, these tools allow for "joint design", "complementarity", "partnership", "common inventory", etc. Obviously, confidence, knowledge of each other, people networking and experience over time are the ingredients that form the roots of collaborative practices. Moreover, some examples suggest that users adapt tools to better fit in their specificity, that call for "learning by doing" and "collective learning" highlighted when building core competencies [64]. In other words, even if these ICTs are not rare, even if they can be replicated everywhere or substituted, they contribute to the building of core competencies of the collaborative supply chain through the knowledge associated. How does one replicate or substitute the long-term intertwined connections among people from companies involved in the common task of adjusting the whole collaborative system supported by the ICTs? It is impossible to do the same. The core competencies stem from the network of people implementing them together in the supply chain. Accordingly, several combinations of techniques are equally valuable, as long as the "network of people" works. This could explain why the different partnerships between retailers and logistics companies quoted in Section 3.5 do not share the same techniques. In a nutshell, the core competency of a collaborative supply chain lies more in the secrecy of collaboration than in the kind of tools in use to support collaboration.

\subsection{So Where Are the POTENTIAL Strategic Resources?}

From the paragraphs of the Section 5, it seems that ICTs have the potential to become a support for core competencies under certain conditions, which differ depending on the kind of supply chain and strategy.

Long supply chains are competing. The ICTs able to provide strategic advantages have the ordinary features of strategic resources, as per [14]. They provide competencies that are precious, rare, difficult to imitate and to substitute. Among the ICTs described in Section 3, the collaborative tools are the best applicant to generate learning-by-doing and human knowledge being strategic resources in the long run. By facilitating work along the supply chain, they become precious, and because they have been adapted to the firms' specificities, they become unique.

Nevertheless, the transformation of the knowledge generated by using collaborative ICTs tools into strategic resources can be jeopardized by unbalanced contributions. Indeed, use of ICTs often "reflect the strategic interests of powerful corporate players and the struggles of those players for domination in the marketplace" [65] (p. 31). More generally, ICTs can be seen as the device of knowledge dependence and even the main tool to shrink the national space for decision making in developing countries [66]. That is why collaborative ICTs are only "potential" for developing strategic resources. This potential is only achieved if the collaboration is balanced among the players. Regarding the club ICTs (ICTs which benefit from the club protection), they are a priori rare, difficult to imitate and to substitute, but there is no guarantee that they are precious enough to support the building of strategic knowledge.

The case of resources in short supply chains (unconnected to worldwide supply chains) is of the utmost interest because they obviously depart from the primary Barney's scope [14]. In fact, this issue refers to the so-called boundaries of applicability of RBV [15]. Using RBV, [67] demonstrated that the nature of the category of resources which proved strategic was different in a stable and in an unstable environment. In the same way, either a large or a small playground makes differences in the nature of the strategic resources. However, the primary resource-based view is about competing firms in the worldwide arena. Limiting the playground to a given small region (where is implemented the shortchain) shifts the rules of competition, and entails, therefore, consequences for the categories of resources which reveal strategic. In practice, within the small region, ICTs implemented in short supply chains generate strategic knowledge if they are (1) useful, what often means if they are simple, accessible and user friendly enough, so that they are easy to share; (2) 
common, so readily available and free as far as possible; and (3) if no one has a benefit in imitating or substituting them. However, the constraints of logistics often push the different local farmers or agrofood companies to pool their offers together, instead of competing on logistics facilities, so as long as the ICTs tools are working smoothly, no local player has interest to imitate or substitute them. This suggests that ICTs tools that are easy to maintain and to repair are the best applicants to generate strategic resources for the short supply chains (unconnected to worldwide supply chains). Table 2 presents a synthesis of the topics discussed in Section 5.4.

Table 2. Suggestion of potential strategic resources for worldwide and local fruit and vegetable supply chains.

\begin{tabular}{cccc}
\hline \multicolumn{2}{c}{ Large Supply Chains } & Mandatory Local Collaboration for Logistics \\
\hline $\begin{array}{c}\text { Warney's definition of strategic } \\
\text { resources }\end{array}$ & $\begin{array}{c}\text { Category of ICTs generating } \\
\text { strategic knowledge }\end{array}$ & $\begin{array}{c}\text { Ad hoc translation of the } \\
\text { Barney's definition of } \\
\text { strategic resources }\end{array}$ & $\begin{array}{c}\text { Category of ICTs } \\
\text { generating performance }\end{array}$ \\
\hline Precious & Collaborative ICTs & $\begin{array}{c}\text { Club ICTs } \\
\text { Collaborative ICTs } \\
\text { user-friendly to share }\end{array}$ & Common \\
\hline $\begin{array}{c}\text { Difficult to imitate and } \\
\text { to substitute }\end{array}$ & $\begin{array}{c}\text { Collaborative ICTs } \\
\text { Club ICTs }\end{array}$ & Working smoothly & Easy to maintain, to repair \\
\hline
\end{tabular}

\section{Future and Sustainability of ICTs in Logistics}

\subsection{Expected Changes Thanks to ICTs?}

Respondents agree that new technologies will transform the sector. They indicated some directions for change. They mentioned increasing the speed of communication and interconnection between objects, and the possibility of communicating with partners directly via certain media presented above. "Sending e-mails is already out of date today", said a representative of a tracker company. A representative of a logistics solutions company hoped digital tools would speed up the paperwork to sign a contract. Nevertheless, he said digital technology could also potentially increase the number of actors involved in decision-making. As a result, the process to sign a contract might slow down.

Other respondents instead mentioned the expected change of context. The growing demand for quality will reinforce the controls carried out in the supply chain. Changes are expected, but the respondents did not give precise details as to how the controls would be reinforced, or how ICT would accompany this demand. However, they pointed out that this revolution is still in its infancy. Digital change is obvious, but it is still too early to determine the modalities of transformation [54]. "There are too many possibilities for evolution, it will depend on consumer demand," said one respondent. More informed authors make the same remark: "The more substantial impact [of ICTs] on the form of supply chains is still to come" [68] (p. 155).

Because of the uncertainties, taking the example of Blockchain, Alan Robertson recommends a period of two or three years of use before seeing the areas to improve on these new instruments. However, no one thinks that new technologies will be able to replace humans. It is noticeable that-at least until now- "the agrofood industry has been evolving according to the technological development in the manufacturing sector" [58] (p. 21). Despite the hesitation of prospects, this historical fact allows us to believe that ICTs will continue to flourish in the agrofood sector.

\subsection{Sustainable Development of Supply Chains through ICTs?}

According to respondents, ICTs will enable "sustainable development" of the logistics sector because they will enable "more efficient activity with fewer resources and fewer 
losses". This efficiency might lie in continuous improvement via "machine learning" systems. Through an iterative process, computers manage to elaborate operational algorithms of their own [62]. Nevertheless, such machine learning techniques do not seem to be running in the fruit and vegetable sector to date. On the other hand, some respondents argued that ICTs will be able to do repetitive tasks in place of humans, so that the latter can focus more on aspects related to sustainable development. Several respondents mentioned that ICTs will save paper. This statement that ICTs save paper deserves to be discussed because life cycle analysis studies of ICTs yields nuanced environmental benefits vis-à-vis paper [69], and paper consumption continues to increase ( $2 \%$ per year) despite the expansion of ICTs [70]. More problematic is the energy intensity increase of the ICT sector itself ( $4 \%$ per year); as such, the contribution of ICTs to the reduction of the environmental footprint of each economic sector should be demonstrated [31]. On one hand, the environmental footprint of ICTs in logistics is more and more documented. On the other hand, ICTs are reputed to allow large emissions savings, but the literature is modest on this topic. In their review of how the freight and logistics service sector accounts for environmental issues, [71] highlight that they found only one paper providing an estimation of the emissions savings [72], and yet only within the scope of the company.

Only one respondent was not convinced, saying that "ICT change is obvious but sustainability is less so". No one knows the transformation modalities. Another noted that the digital evolution could be all the more sustainable because it is compatible with the economic interests of stakeholders. From the social scope, spreading ERP increases the productivity of human work, entailing the rebound effect of multiplying the number of tasks devoted to one worker [70].

No respondent noted the problematic loss of autonomy vis-à-vis the ICTs company owning the licenses and software used in their own enterprise. Indeed, adopting sophisticated ICTs tools in the fruit and vegetable supply chain involves a newcomer. Whether a small ICTs start-up or a large experienced company, the adoption extends the supply chain and lowers the autonomy (ICTs tools maintenance, updates, repairs ... ) of the traditional players.

\subsection{The Opinion of Experts}

In the opinion of Cirad experts (consulted before the Covid-19 pandemic), three main trends stand out for the production stage (farm, plantation, etc.). First, biotic forces such as invasive diseases (e.g., citrus greening) and abiotic forces such as heat waves caused by global warming (e.g., melon shortage in Europe in summer 2019) are threatening the smooth supply of fruit and vegetables. Second, in Europe, many clues attest that the trends of globalization, specialization of regions, monofunctionality and free-trade contracts are over. Because of the long recession following the 2008 crisis, the emergence of populist movements in Western countries and renewed protectionist policies: "there is evidence that MNEs [multinational enterprises] are reorienting their internationalization strategies by changing the parameters of their production location choices" [68] (p. 155). Third, citizens hold enterprises and governments to account for use of pesticides and for any other risk (e.g., decline of pollinating insects, birds). In the coming years, agriculture has to cope with all these trends, which obviously affect the rest of the supply chain also.

Today, mass distribution faces two main problems that are more visible in Europe, but are relevant worldwide. First, the mass model (uniform products and prices) does not work anymore. For the large retailing French brands, the latest panel data on fruit and vegetable depict, at best, a loss in sales volume while the sales value remains stable. In general, loss in both volume and value go hand-in-hand. Second, the customers are increasingly split into two groups, which are not manageable together in the same retail space. Some (around 30\% of the customers in France) are still seeking low prices, and purchase mass production, even if it is low quality. As the traditional "discount" retailers (Aldi, Lidl ... ) are improving the quality (and so price) of the proposed goods, newcomers (hyperdiscount warehouses) charging very low prices are appearing, to match the demand 
of this first group of customers. A second group of customers agrees to pay a little more for quality. Nevertheless, they are looking also at specialized stores (e.g., Grandfrais, BioCoop), local markets and short supply chains. As a result, the model of mass production and mass logistics of the mass distribution brands is being challenged from everywhere.

At the "in-between" step of wholesalers, fruit and vegetable processors, road haulers, brokers and other intermediates, all opportunities are open. Indeed, the booming diversification in the business models creates new branches in the network of actors of the fruit and vegetable sector, and argues for a renewed variety of services.

In such a business upheaval, what about ICTs? First, the fruit and vegetable sector is slow to evolve. In global value chains, the fruit and vegetable sector is burdened by sunk coordination costs (which hamper reshoring) whatever the sense, as any other sector [73]. Once the organization of the supply chain has been set, it is difficult to upset the order, and even to introduce new tools to replace old ones. The business margins are tiny [74], so the players do not have time nor money to undertake adventurous experiments. On many occasions, actors introduced innovations that seemed to be relevant at first (like sensors in containers ... ) but gave them up after a while, often because they proved inappropriate to the work tempo. The low adoption is confirmed by the calculation of the "revealed physical capital intensity in the US" for the years 1988 to 2014, that displays that in the low-skill sectors (to which the fruit and vegetable sector belongs), new technologies are not replacing low-skill routine occupations [68].

Therefore, the present ICTs which have been adopted for several years in a given company are likely to remain in place for the long term. Conversely, in case of recent ICTs adoption, it is impossible to pretend they will last, as noted by Alan Robertson above. Moreover, in many cases, the dominant actor of the supply chain (e.g., retailer) encourages the others (e.g., the producer) to equip themselves with new tools (e.g., Blockchain) to meet new requirements. In the context of current business upheavals (e.g., increasing scarcity of certain agricultural resources), the power balance can shift, as well as the required ICT tools.

Conversely, new breakthrough services provided by ICTs could appear in the future, entailing large adoption. Thus, thanks to the development of intelligent objects, one can imagine that containers can integrate the information collected and adjust to correct the parameter automatically. More generally, ref. [74] suggests that the IoT (internet of things) is prone to serve as capacity-sensing, planning and reporting of delivery, route optimization, energy management, and fault detection and resolution. In collaboration with the IoT, improved Blockchain could provide "trustworthy public listing of services and information" [75]. Ref. [76] depicts the tasks that would benefit from automation in logistics: material handling upon arrival, primary processing (sorting), quality monitoring, packaging and palletizing. In warehouse logistics, [74] recommends the use of automated guided vehicles and robots. For logistics systems as a whole, modeling and simulation would allow testing of new configurations and would predict system performance without any risk [74]. They also discuss the interest for the food supply chain of system integration (process of connecting various subsystems into one cooperating system) and of increased adoption of IoT.

Sophisticated ICT requiring frequent interventions, or when the investment in the design of the tool has been enormous for the design company, leads to a paradox concerning its diffusion. There is a conflict between, on one hand, the interests of the designer company, and on the other hand the interests of the agrofood sector. Indeed, the former seeks to diffuse their own ICTs to as many customer companies as possible, whereas the latter would prefer the ICTs to be a "club" good or, better yet, designed for their own use only. As illustrated in Section 3.5 for long chains, the proliferation of cases where a retailer is associated with one ICTs designer (often a start-up) to perform a tailor-made "Blockchain" attests to this trend.

As already noted, questions can be asked over the long-term future of certain ICTs because of their environmental footprint. 


\section{Conclusions}

The rise of new technologies, relayed by the various and numerous actors of the digital ecosystem, is accompanying the present transformation of fruit and vegetable supplychains. Internet searches, conferences attendance and interviews of supply chain players provided a state-of-the-art analysis on ICTs adopted in the fresh fruit and vegetable supply chain to date. The gathered material was used to analyze the potential and weaknesses for certain ICTs to support strategic resources for individual companies or for the supply chain as a whole, and to sketch some outlooks regarding the future of ICTs within this sector.

Within the fruit and vegetable supply chains, ICTs are split between several usages. Multitasking tools like the mobile phone are present at any step of the supply chain, and whatever the social context. Nevertheless, the under-development of infrastructures often hampers usages requiring web access, for a large part of developing countries. Generalist tools like email or EDI mainly run in a developed context, for long and short chains as well. In the same developed context, specific software like ERP and WMS have been designed to optimize the internal logistics of companies and are important in long-chains, whereas short-chains mobilize humbler more basic functional equivalents. Blockchains and sensors are parts of the ICTs designed to manage (and avoid) conflicts between partners of the supply-chain around transportation. This "litigation management" is more and more common in the long-chains of developed countries and provides traceability for consumers. However, we found few revolutionary items belonging to the Industry 4.0 trend, as recently confirmed by [74] who noticed that "Industry 4.0 technologies are only recently beginning to be adopted" in food logistics.

The collaborative ICTs involve several partners to facilitate flow fluidity through the supply chain. The tool is at least adapted to the specificity of the given chain (if not exclusively devoted to the chain), and this makes it unique. Long and short chains in the developed context run collaborative ICTs, each according to its means. In traditional retail markets, equivalent mobile-phone-based software is sometimes available.

Among this panorama, some are prone to create strategic resources because they support the building of core competencies that are precious to the supply chain, rare, and difficult to imitate or to substitute. In the fruit and vegetable sector, the so-called collaborative tools, because of the learning-by-doing and human knowledge supported, are the best applicants to generate strategic resources in the long run. Some other results are worthy of comment. It seems that there is no construction of strategic resources when handled by one company alone. Indeed, the "club" effect means that a group of companies reserves the right to run the ICT in trusted relationships. This is all the more obvious for collaborative tools implemented within the same supply chain between partners. The lesson learnt might be that the strategic resources of the future are assets voluntarily and collectively developed by partners in a relationship of trust.

As expected from its properties, the digital ecosystem surrounding the food network is self-organizing, and it weaves complex interdependencies between and across the technological and the social environment, which can hardly be comprehensively deciphered today.

Author Contributions: AConceptualization, R.T., C.M. and D.L.; methodology, C.M. and R.T.; software, not relevant; validation, C.M., R.T. and D.L; formal analysis, C.V. and C.M.; investigation, C.V.; resources, D.L.; data curation, C.M.; writing—original draft preparation, R.T. and C.M.; writingreview and editing, C.V., D.L., C.M. and R.T.; visualization, R.T.; supervision, C.M. and R.T.; project administration, C.M.; funding acquisition, C.M. All authors have read and agreed to the published version of the manuscript.

Funding: This work was supported by the French National Research Agency under the Investments for the Future Program, referred to as ANR-16-CONV-0004.

Conflicts of Interest: The authors declare no conflict of interest. 


\section{References}

1. Fruit Logistica. Disruption in the Fruit and Vegetables Distribution: Fruit Logistica Trend Report 2018. Part 1-The Fruit and Veg Market Is Set to Double in Size. 2018. Available online: https:/ / fr.scribd.com/document/425003736/Fruit-Logistica-TrendReport-2018-Part1 (accessed on 8 June 2021).

2. United Nations. Resolution Adopted by the General Assembly on 6 July 2017, Work of the Statistical Commission Pertaining to the 2030 Agenda for Sustainable Development (A/RES/71/313 Archived 28 November 2020 at the Wayback Machine). 2017. Available online: https://undocs.org/A/RES/71/313 (accessed on 8 June 2021).

3. Raut, R.D.; Gardas, B.B.; Narwane, V.S.; Narkhede, B.E. Improvement in the food losses in fruits and vegetable supply chain-a perspective of cold third-party logistics approach. Oper. Res. Perspect. 2019, 6, 100117. [CrossRef]

4. Fonseca, I.M.; Vergara, N. Logistics systems need to scale up reduction of produce losses in the Latin America and Carribean region. Acta Hortic. 2014, 1047, 173-179. [CrossRef]

5. Van Hooijdonk, R. The Future of Logistics and Supply Chain Management. Inspiration Series. 2018. Available online: https: / / richardvanhooijdonk.com/en/ebooks/future-logistics-supply-chain-management (accessed on 19 March 2020).

6. Barratt, M. Understanding the meaning of collaboration in the supply chain. Supply Chain Manag. 2004, 9, 30-42. [CrossRef]

7. Vial, G. Understanding digital transformation: A review and a research agenda. J. Strateg. Inf. Syst. 2019, 28, 118-144. [CrossRef]

8. Khanal, M.P. Information Structure and Coordination in Vegetable Supply Chains. Ph.D. Thesis, Lincoln University, Lincoln, PA, USA, 2012. Available online: https:/ / researcharchive.lincoln.ac.nz/handle/10182/5053 (accessed on 8 June 2021).

9. De La Fuente, M.; Ros-McDonnell, L. Cold Supply Chain Processes in a Fruit- and-Vegetable Collaborative Network. IFIP Adv. Inf. Commun. Technol. 2010, 322, 3-10. [CrossRef]

10. European Parliament-Directorate-General for Internal Policies. Logistics as an Instrument for Tackling Climate Change; Publications Office: Luxembourg, 2010. Available online: http://www.europarl.europa.eu/RegData/etudes/etudes/join/2010/431585/ IPOL-TRAN_ET(2010)431585_EN.pdf (accessed on 8 June 2021).

11. Grenier, G. Technologies de L'information et de la Communication: Vers une Agriculture Pilotée par les Données. Demeter, 15. 2016. Available online: https://s1.membogo.com/company/CPYeQ231LcPYvZ9GTj339cZ7/asset/files/technologies_de_1_ information_et_de_la_communication_vers_une_agriculture_pilotee_par_les_donnees.pdf (accessed on 8 June 2021).

12. Nair, P.R. Emerging ICT Tools for Virtual Supply Chain Management: Evidences from Progressive Companies. In ICT and Critical Infrastructure: Proceedings of the 48th Annual Convention of Computer Society of India; Satapathy, S., Avadhani, P., Udgata, S., Lakshminarayana, S., Eds.; Springer: Cham, Switzerland, 2014; Volume II, pp. 715-722. [CrossRef]

13. IAU. Les Filières Courtes de Proximité au Sein du Système Alimentaire Francilien. Focus sur la Logistique et les Flux de Transport; Institut D'amenagement et d'Urbanisme Île de France: Paris, France, 2015. Available online: https: / /www.iau-idf.fr / fileadmin/ NewEtudes/Etude_1222/fascicule5_Les_filieres_courtes_de_proximite.pdf (accessed on 8 June 2021).

14. Barney, J.B. Firm resources and sustained competitive advantage. J. Manag. 1991, 17, 99-120. [CrossRef]

15. Priem, R.L.; Butler, J.E. Is the Resource-Based "View" a Useful Perspective for Strategic Management Research? Acad. Manag. Rev. 2001, 261, 22-40.

16. Hamel, G.; Prahalad, C.K. Strategic Intent; Harvard Business Review, Harvard Business Publishing: Harvard, MA, USA, 1989; pp. 63-76.

17. Hsiao, Y.H.; Chen, M.C.; Lu, K.Y.; Chin, C.L. Last-mile distribution planning for fruit-and-vegetable cold chains. Int. J. Logist. Manag. 2018, 29, 862-886. [CrossRef]

18. Perego, A.; Perotti, S.; Mangiaracina, R. ICT for logistics and freight transportation: A literature review and research agenda. Int. J. Phys. Distrib. Logist. Manag. 2011, 41, 457-483. [CrossRef]

19. Djekic, I.; Mujčinović, A.; Nikolić, A.; Jambrak, A.R.; Papademas, P.; Feyissa, A.H.; Kansou, K.; Thomopoulos, R.; Breisen, H.; Kavallieratos, N.; et al. Cross-European analysis on the use of mathematical models in food industry. J. Food Eng. 2019, 261, 109-116. [CrossRef]

20. Corò, G.; Volpe, M. Driving factors in the adoption of Industry 4.0 technologies. In Industry 4.0 and Regional Transformations, Chapter 7; de Propis, L., Bailey, D., Eds.; Routledge: Oxon, UK, 2020; pp. 112-132.

21. Bluhm, D.J.; Harman, W.; Lee, T.W.; Mitchell, T.R. Qualitative Research in Management: A Decade of Progress. J. Manag. Stud. 2011. [CrossRef]

22. Paillé, P.; Mucchielli, A. L'analyse Qualitative en Sciences Humaines et Sociales, 4th ed.; Armand Colin: Paris, France, 2016.

23. Thiétart, R.A. Méthodes de Recherche en Management, 4th ed.; Dunod: Paris, France, 2014.

24. Charmaz, K. Constructing Grounded Theory: A Practical Guide through Qualitative Analysis; Sage: London, UK, 2006.

25. Hsiao, H.I.; van des Vorst, J.G.A.J.; Omta, S.W.F. Logistics outsourcing in food supply chain networks: Theory and practice. In International Agricfood Chains and Networks; Bijman, J., Omta, S.W.F., Trienekens, J.H., Wijnands, J.H.M., Wubben, E.F.M., Eds.; Management and Organization, Wageningen Academic Publishers: Wageningen, The Netherlands, 2006.

26. Gupta, A.; Mattarelli, E.; Seshasai, S.; Broschak, J. Use of collaborative technologies and knowledge sharing in co-located and distributed teams: Towards the 24-h knowledge factory. J. Strateg. Inf. Syst. 2009, 18, 147-161. [CrossRef]

27. Rouchier, J. Compétences des Grossistes en Fruits et Légumes de Marseille: Gestion des Flux et des «Coups». Aix-Marseille School of Economics. 2004. Available online: https://intranet.amse-aixmarseille.fr/sites/default/files/_dt/greqam/2004-37.pdf (accessed on 31 March 2018). 
28. Kabbiri, R.; Dora, M.; Kumar, V.; Elepu, G.; Gellynck, X. Mobile phone adoption in agri-food sector: Are farmers in Sub-Saharan Africa connected? Technol. Forecast. Soc. Chang. 2018, 131, 253-261. [CrossRef]

29. Indochina Research Ltd. Cambodia-Canada Market Information Project (CAMIP). Fruits and Vegetables Traders: Baseline Study (Research Report); Indochina Research Limited: Phnom Penh, CA, USA, 2007. Available online: http://www.value-chains.org/dyn/bds / docs /652/CAMIPTradersStudyCambodia2007.pdf (accessed on 8 June 2021).

30. Vesper, I. Succès Mitigé des Applications Mobiles Chez les Agriculteurs. 2018. Available online: https://www.scidev.net/afriquesub-saharienne/tic/actualites/applications-mobiles-agriculteurs.html (accessed on 19 March 2020).

31. Ferreboeuf, H. Lean ICT-Pour une Sobriété Numérique, Rapport du Groupe de Travail Pour le Think Tank the SHIFT ProjectOctobre 2018. Available online: https://theshiftproject.org/wp-content/uploads/2018/10/2018-10-04_Rapport_Pour-unesobriété-numérique_Rapport_The-Shift-Project.pdf (accessed on 8 June 2021).

32. INSEE. Définition-Échange de Données Informatisé/EDI/EDI/Insee. 2019. Available online: https://www.insee.fr/fr/ metadonnees/definition/c1026 (accessed on 19 March 2020).

33. Chiffoleau, Y.; Bouré, M.; Akermann, G. Les circuits courts alimentaires à l'heure du numérique: Quels enjeux? Une exploration. Innov. Agron. 2018, 67, 37-47.

34. Auclair, F. Organisation Collective de la Logistique Dans les Circuits Courts Alimentaires (Research Summary). Fncuma, France, 2014. Available online: http://www.cuma.fr/sites/default/files/2014_03_28_dossier_collaborations_logisitques_circuits_courts. pdf (accessed on 8 June 2021).

35. Solard, G. (Ed.) Logistique alimentaire: A la recherche de nouveaux repères. In Stratégies Logistique, Special Edition LOGISTIAA, No 9; Editions Presse Pilote: Pontoise, France, 2016.

36. Zetes. Marks and Spencer Choisit Zetes Pour Réformer ses Opérations D'approvisionnement Alimentaire (Press Release). 2018. Available online: https://www.zetes.com/fr/solutions-de-bout-en-bout/systeme-de-visibilite-supply-chain/marks-andspencer-choisit-zetes-pour (accessed on 8 June 2021).

37. Agreste. L'utilisation des Technologies de L'information et de la Communication dans L'agroalimentaire en 2017. Agreste Chiffres et Données Agroalimentaire, 190. 2018. Available online: http://agreste.agriculture.gouv.fr/IMG/pdf/CD190bsiaa.pdf (accessed on 19 March 2020).

38. Knwoles, M. Blockchain: Dole and Driscoll's on Board. 2017. Available online: http://www.fruitnet.com/eurofruit/article/1731 70/blockchain-dole-and-driscolls-on-board (accessed on 8 June 2021).

39. Wyman, O. Use Blockchain to Secure the Supply Chain. 2017. Available online: https://www.oliverwyman.com/content/dam/ oliver-wyman/v2/publications/2017/oct/digital-procurement-chapter-3.pdf (accessed on 8 June 2021).

40. Massa, A. Someone Figured Out How to Put Tomatoes on a Blockchain. 2017. Available online: https://www.bloomberg.com/ news/articles/2017-11-09/the-internet-of-tomatoes-is-coming-starting-with-boston-salads (accessed on 19 March 2020).

41. Gros, M. 10 Géants de L'agroalimentaire Explorent Blockchain Avec IBM. 2017. Available online: https:/ / www.lemondeinformatique. fr/actualites/lire-10-geants-de-l-agroalimentaire-explorent-blockchain-avec-ibm-69109.html (accessed on 8 June 2021).

42. Pelletier, W.; Brecht, J.K.; Do Nascimento Nunes, M.C.; Emond, J.P. Quality of Strawberries Shipped by Truck from California to Florida as Influenced by Postharvest Temperature Management Practices. HortTechnology 2011, 21, 482-493. [CrossRef]

43. Ingrand, C.; Sandretto, A.; Legardez, M.; Frénod, E.; Grumiaux, T.; Fenrique, L.; Bouallouche, Y.; Lenhartz, C. Regards sur L'innovation Logistique dans le Monde: Révolution, Disruption ou Transition Digitale? Où en est l'Europe Dans Cette Nouvelle Bataille Mondiale? SITL: Villepinte, France, 2018.

44. Fenayrou, C. Zoom sur la Transformation Digitale des Circuits Courts. 2017. Available online: http://www.mbadmb.com/zoomtransformation-digitale-circuits-courts-france/ (accessed on 19 March 2020).

45. Oliveira, A.; Barratt, M. Exploring the experiences of collaborative planning initiatives. Int. J. Phys. Distrib. Logist. Manag. 2011, 31, 266-289. [CrossRef]

46. Demolin, A.; Freydier, P.; Montigny, B.; Apostolova-Riekl, N.; Bergé-Lefranc, C. Supply Chain 4.0: Mythes ou Réalités? SITL: Villepinte, France, 2018.

47. JD.com. Walmart and JD.com Expand Strategic Cooperation (Press Release). 2017. Available online: https://www.globenewswire. com/news-release/2017/07/25/1057519/0/en/Walmart-and-JD-com-Expand-Strategic-Cooperation.html (accessed on 8 June 2021).

48. Merlaud, B. Carrefour Livré Chez Vous, Dernier-né de la Galaxie Carrefour. 2018. Available online: http://www.lineaires.com/ LA-DISTRIBUTION/Les-actus / Carrefour-livre-chez-vous-dernier-ne-de-la-galaxie-Carrefour-51819 (accessed on 8 June 2021).

49. Villeroy, E. Intermarché Fait Appel à Shopopop Pour Développer la Livraison Collaborative à Domicile. 2018. Available online: http:/ / www.voxlog.fr/actualite/2852/intermarche-fait-appel-a-shopopop-pour-developper-la-livraison-collaborativea-domicile (accessed on 8 June 2021).

50. Bosona, T.; Gebresenbet, G.; Nordmark, I.; Ljungberg, D. Integrated Logistics Network for the Supply Chain of Locally Produced Food, Part I: Location and Route Optimization Analyses. J. Serv. Sci. Manag. 2011, 4, 174-183. [CrossRef]

51. Bastin, C. La Charrette, un « Blablacar des Producteurs » Pour Développer Les Circuits Courts. 2018. Available online: http: / / consocollaborative.com/article/la-charrette-un-blablacar-des-producteurs-pour-developper-les-circuits-courts / (accessed on 19 March 2020).

52. Kurnia, S.; Johnston, R.B. The need for a processual view of inter-organizational systems adoption. J. Strateg. Inf. Syst. 2000, 9 , 295-319. [CrossRef] 
53. Fruit Logistica. Disruption in the Fruit and Vegetables Distribution: Fruit Logistica Trend Report 2018. Part 2-Is this the End of 'Retailer vs. Supplier'? 2018. Available online: https:/ /www.oliverwyman.com/content/dam/oliver-wyman/v2-de/ publications/2018/Feb/Fruit_Logistica_Trend_Report_2018.pdf (accessed on 8 June 2021).

54. Robertson, A. Will Blockchain Revolutionize the Global Perishable Supply Chain? Fruit Logistica: Berlin, Germany, 2018.

55. Petzold, S.; Carpenter, M. Coopetition, a stabilizing strategy in traditional sectors? Ann. Mines 2015, 120, 35-46.

56. Monin, J.; Imbert, C.; Tranchet, S.; Dupouy Hennequin, L. Grande Distribution: Négociations Impitoyables. 2016. Available online: https:/ / www.franceinter.fr/emissions/l-enquete-de-secrets-d-info/l-enquete-de-secrets-d-info-25-novembre-2016 (accessed on 19 March 2020).

57. Suire, R.; Vicente, J. Récents enseignements de la théorie des réseaux en faveur de la politique et du management des clusters. Rev. D'économie Ind. 2015, 152, 91-119. [CrossRef]

58. Miranda, J.; Ponce, P.; Molina, A.; Wright, P. Sensing, smart and sustainable technologies for Agri-Food 4.0. Comput. Ind. 2019, 108, 21-36. [CrossRef]

59. Palier, B. Path dependence. In Dictionnaire des Politiques Publiques, 3rd ed.; Presses de Sciences Po.: Paris, France, 2010; pp. 411-419. Available online: https:/ / www.cairn.info/dictionnaire-des-politiques-publiques--9782724611755-p-411.htm (accessed on 8 June 2021).

60. Harindranath, G.; Dyerson, R.; Barnes, D. ICT Adoption and Use in UK SMEs: A Failure of Initiatives? Electron. J. Inf. Syst. Eval. 2008, 11, 91-96. Available online: http:/ / citeseerx.ist.psu.edu/viewdoc/download;jsessionid=EDA5D27AADE6ADDEE57D852 B7D8DD200?doi=10.1.1.217.2825\&rep=rep1\&type=pdf (accessed on 8 June 2021).

61. Schmeittz, H. Future Retail Development and Its Impact on Logistics; Fruit Logistica: Berlin, Germany, 2018.

62. Sega, C.; Winter, G. Fruit Trade 4.0 from ERP to Artificial Intelligence; Fruit Logistica: Berlin, Germany, 2018.

63. Shuchih, E.C.; Chen, Y.-C.; Lu, M.-F. Supply chain re-engineering using blockchain technology: A case of smart contract based tracking process. Technol. Forecast. Soc. Chang. 2019, 144, 1-11.

64. Hamel, G. The concept of core competence. In Competence-Based Competition; Hamel, G., Heene, A., Eds.; Wiley/SMS: New York, NY, USA, 1994; pp. 11-33.

65. Webster, J. Networks of collaboration or conflict? Electronic data interchange and power in the supply chain. J. Strateg. Inf. Syst. 1995, 4, 31-42. [CrossRef]

66. Ya, Y.Z. The New Imperialism \& Africa in the Global Electronic Village. Rev. Afr. Political Econ. 2004, 31, 11-29. Available online: www.jstor.org/stable/4006937 (accessed on 31 May 2021).

67. Miller, D.; Shamsie, J. The resource-based view of the firm in two environments: The Hollywood film studios from 1936 to 1965. Acad. Manag. J. 1996, 39, 519-543.

68. Pegoraro, D.; Propris, L.; Chidlow, A. De-globalisation, value chains and reshoring. In Industry 4.0 and Regional Transformations, Chapter 9; de Propis, L., Bailey, D., Eds.; Routledge: Oxon, UK, 2020; pp. 152-175.

69. Tinetti, B.; Duvernois, P.A.; Le Guern, Y.; Berthoud, F.; Charbuillet, C.; Gossart, C.; Orgerie, A.C.; Lefèvre, L.; De Jouvenel, F.; Desaunay, C.; et al. Potentiel de Contribution du Numérique à la Réduction des Impacts Environnementaux: Etat des Lieux et Enjeux pour la Prospective-Rapport Final; ADEME: Paris, France, 2016; 145p.

70. Vivat, F. Enjeux Environnementaux, Sociaux, Economiques Liés Au TIC. Seminar Presented at the Training on Eco-Responsibility of the X/Stra Group, Strasbourg, France. 2013. Available online: https:/ / ecoinfo.cnrs.fr/wp-content/uploads/2015/01/EnjeuxStg-2013.pdf (accessed on 8 June 2021).

71. Evangelista, P.; Santoro, L.; Thomas, A. Environmental Sustainability in Third-Party Logistics Service Providers: A Systematic Literature Review from 2000-2016. Sustainability 2018, 10, 1627. [CrossRef]

72. Oberhofer, P.; Dieplinger, M. Environmental Management in the Transport and Logistics Sector: Findings from a Qualitative Study. Business Strategy and the Environment. 2013. Available online: http:/ / epub.wu.ac.at/4028 (accessed on 8 June 2021).

73. Antràs, P. De-Globalisation? Global Value Chains in the Post-Covid-19 Age; Working Paper 28115; National Bureau of Economic Research: Cambridge, MA, USA, 2020. Available online: http:/ / www.nber.org/papers/w28115 (accessed on 8 June 2021).

74. Jagtap, S.; Bader, F.; Garcia-Garcia, G.; Trollman, H.; Fadiji, T.; Salonitis, K. Food Logistics 4.0: Opportunities and Challenges. Logistics 2021, 5, 2. [CrossRef]

75. Rožman, N.; Vrabič, R.; Corn, M.; Požrl, T.; Diaci, J. Distributed logistics platform based on Blockchain and IoT. Procedia CIRP 2019, 81, 826-831. [CrossRef]

76. Pal, A.; Kant, K. Internet of Perishable Logistics: Building Smart Fresh Food Supply Chain Networks. IEEE Access 2019, 7, 17675-17695. [CrossRef] 